\title{
Ion Channels Permeable to Monovalent and Divalent Cations: A Single-File Two-Site Channel Model
}

\author{
Yoshio OOSAWA \\ International Institute for Advanced Research, Matsushita Electric Industrial Co. Ltd., \\ Seika-cho, Souraku-gun, Kyoto, 619-0237 Japan
}

\begin{abstract}
A cation channel from Tetrahymena cilia is permeable to both monovalent and divalent cations. A single-file two-site channel model was introduced for explaining the single channel currents of the channel in mixed solutions of $\mathrm{K}^{+}$ and $\mathrm{Ca}^{2+}$. In the model it was assumed that two potassium ions or one calcium ion can bind to the binding sites, and that the potassium ions between the binding sites are in a fast equilibrium condition. Single channel currents were calculated from the values of rate constants, ionic concentrations on both sides of the membrane, and
\end{abstract}

the membrane voltages. This model could explain all the observed single channel currents of the channel in $\mathrm{K}^{+}$or $\mathrm{Ca}^{2+}$ solution and in mixed solutions of $\mathrm{K}^{+}$and $\mathrm{Ca}^{2+}$. The values of the reversal potential in the bi-ionic condition could distinguish this single-file two-site channel model from the single-site channel model or the model in which each ion permeates through the same channel independently (the Goldman-HodgkinKatz equation). Experimental data supported this model. [Japanese Journal of Physiology, 51, 569-576, 2001]

Key words: nonselective cation channel, multi-ion channel, rate theory, ion permeation, Tetrahymena.

Originally ion channels were thought to permeate only one kind of ion. For example, the $\mathrm{K}^{+}$channel was thought to permeate only $\mathrm{K}^{+}$, and the $\mathrm{Ca}^{2+}$ channel was thought to permeate only $\mathrm{Ca}^{2+}$. However, some channels are known to be permeable not only to divalent cations, but also to monovalent cations. These include calcium channels [1-8], the nicotinic acetylcholine receptor channel $[9,10]$, the NMDA receptor channel [11], and the cyclic nucleotide-gated channel [12-15].

Single-site Eyring rate theory models have been used to account for macroscopic data of the cyclic nucleotide-gated channel from rods with monovalent and divalent cations [15-18]. Haynes [19, 20] fitted single-channel data from multiple cone patches by using a single-site model. Wells and Tanaka [21] developed a two-site, Eyring rate theory model of ionic permeation for cyclic nucleotide-gated channels.

Many mutagenesis experiments have revealed that some amino acids in the pore are important in the ion selectivity of the channel, and some negatively charged amino acids may interact with permeable cations [22-24]. These findings may help to understand ion permeation mechanisms through the channel. It is important to construct an ion permeation model for channels that are permeable to both divalent and monovalent cations. We have previously shown that the single channel conductance of the Tetrahymena cation channel is controlled by the Gibbs-Donnan ratio of $\mathrm{K}^{+}$and $\mathrm{Ca}^{2+}$ and proposed a model for the permeation of monovalent and divalent cations through this channel [25]. In the model, we assumed that two potassium ions or one calcium ion was bound to the channel. This model was improved by using a two-barrier model to calculate the single channel current [26], where we assumed that two potassium ions could bind the binding sites simultaneously, but potassium ions permeated independently, and only one calcium ion could bind the binding sites. This model was not a single-file model.

Received on August 4, 2000; accepted on June 26, 2001

Correspondence should be addressed to: Yoshio Oosawa, 50A Sakuma-biru, 1-19 Kawaharadori, Showa-ku, Nagoya, 466-0853 Japan. Tel: +81-52-762-2219, E-mail: oosawayo@sannet.ne.jp 
Here we show a single-file two-site model that includes double occupancy of potassium ions and single occupancy of a calcium ion. We assume that the central barrier is so low that the ions at the two binding sites are nearly in equilibrium. We calculate the single channel currents in mixed solutions of $\mathrm{K}^{+}$and $\mathrm{Ca}^{2+}$ and compare this result with the data obtained in the experiments. The model presented here can explain all data. A structure analysis of the potassium channel showed that its selectivity filter was single file and contained two potassium ions [27].

\section{RESULTS}

Planar lipid bilayer experiments were done as described previously $[25,28]$. From symmetrical solutions of $\mathrm{K}^{+}$or $\mathrm{Ca}^{2+}$ and symmetrical mixed solutions of $\mathrm{K}^{+}$and $\mathrm{Ca}^{2+}$, similar absolute values of single channel currents were obtained at +25 and $-25 \mathrm{mV}$. We use values of single channel currents obtained at $+25 \mathrm{mV}$ in these calculations. We previously showed that the single channel conductance of the Tetrahymena cation channel was controlled by the Gibbs-Donnan ratio and postulated that two potassium ions or one calcium ion can bind the channel simultaneously [25], which we also postulate in this paper.

\section{A single-file two-site model in $\mathrm{K}^{+}$solution}

We show a single-file two-site model to explain the channel by which two $\mathrm{K}^{+}$ions can simultaneously bind to the two binding sites $\left(\mathrm{B}_{1}\right.$ and $\left.\mathrm{B}_{2}\right)$ in the pore of the channel. Figure 1 shows a single-file two-site model. Rate constants in Fig. 1 are voltage-dependent and can be written as

$$
\begin{gathered}
k_{\mathrm{C} 2}=k_{\mathrm{Ci}} \exp \left[z F\left(1-\delta_{1}-\delta_{2}\right) \varepsilon_{2}(-V) / R T\right] \\
k_{\mathrm{C}-2}=k_{\mathrm{C}-\mathrm{i}} \exp \left[z F\left(1-\delta_{1}-\delta_{2}\right)\left(1-\varepsilon_{2}\right) V / R T\right] \\
k_{\mathrm{C} 1}=k_{\mathrm{Cb}} \exp \left[z F \delta_{1}\left(1-\varepsilon_{1}\right)(-V) / R T\right] \\
k_{\mathrm{C}-3}=k_{\mathrm{C}-\mathrm{b}} \exp \left[z F \delta_{2}\left(1-\varepsilon_{3}\right) V / R T\right] \\
k_{\mathrm{C}-1}=k_{\mathrm{C}-\mathrm{f}} \exp \left[z F \delta_{1} \varepsilon_{1} V / R T\right] \\
k_{\mathrm{C} 3}=k_{\mathrm{Cf}} \exp \left[z F \delta_{2} \varepsilon_{3}(-V) / R T\right]
\end{gathered}
$$

The suffix $\mathrm{C}$ stands for $\mathrm{K}^{+}$or $\mathrm{Ca}^{2+}$ and $z$ equals one for $\mathrm{K}^{+}$and two for $\mathrm{Ca}^{2+}$. The quantities $\delta_{1}$ and $\delta_{2}$ represent the fraction of the total electrical potential drop, $V$, between the outside or inside of the membrane and the ion binding site, respectively [29]. This is often called the electrical distance. The quantities $\varepsilon_{1}, \varepsilon_{2}$,

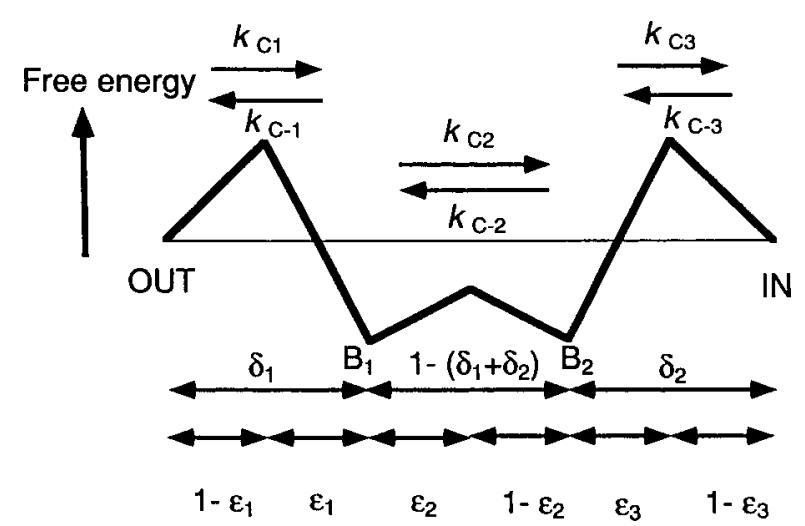

Fig. 1. The single-file two-site model. A hypothetical channel is shown with three barriers (one small one) and two binding sites. The rate constants $k_{\mathrm{C}_{1}}$ and $k_{\mathrm{C}-3}$ are rates of binding, whereas $k_{\mathrm{C}-1}$ and $k_{\mathrm{C} 3}$ are rates of release. The rate constants $k_{\mathrm{C} 2}$ and $k_{\mathrm{C}-2}$ are rates of binding between two binding sites. The energy profile for the hypothetical channel is shown with the energy wells at $B_{1}$ and $B_{2}$.

and $\varepsilon_{3}$ represent the fractions of the electrical potential drop between the ion binding site and the energy maxima (Fig. 1). $k_{\mathrm{Ci}}, k_{\mathrm{C}-\mathrm{i}}, k_{\mathrm{Cb}}, k_{\mathrm{C}-\mathrm{b}}, k_{\mathrm{Cf}}$, and $k_{\mathrm{C}-\mathrm{f}}$ represent the voltage-independent elements of the rate constants.

We assume that two energy maxima except the central energy maximum are equal and that the barriers are symmetrical; thus the value of $\delta_{1}$ equals $\delta_{2}(=\delta)$, $\varepsilon_{1}$ equals $\varepsilon_{3}(=\varepsilon)$, and $\varepsilon_{2}$ is 0.5 , and the value of $k_{\mathrm{Ci}}$ equals $k_{\mathrm{C}-\mathrm{i}}\left(=k_{\mathrm{Ci}}\right), k_{\mathrm{Cb}}$ equals $k_{\mathrm{C}-\mathrm{b}}\left(=k_{\mathrm{Cb}}\right)$, and $k_{\mathrm{Cf}}$ equals $k_{\mathrm{C}-\mathrm{f}}\left(=k_{\mathrm{Cf}}\right)$. Experimentally the single-channel conductance was the same whether the net current was inward or outward in symmetric solutions [28]. We also assume that the central energy maximum is low.

The probabilities, $P$, of potassium ion occupancy of two binding sites are described as follows. Both sites are empty: $P\left(\mathrm{~B}_{1}, \mathrm{~B}_{2}\right) ; \mathrm{B}_{1}$ site is empty and $\mathrm{B}_{2}$ site binds $\mathrm{K}^{+}: P\left(\mathrm{~B}_{1}, \mathrm{~B}_{2} \mathrm{~K}\right) ; \mathrm{B}_{1}$ site binds $\mathrm{K}^{+}$and $\mathrm{B}_{2}$ site is empty: $\quad P\left(\mathrm{~B}_{1} \mathrm{~K}, \mathrm{~B}_{2}\right)$; and both sites bind $\mathrm{K}^{+}$: $P\left(\mathrm{~B}_{1} \mathrm{~K}, \mathrm{~B}_{2} \mathrm{~K}\right)$. They are expressed by the probabilities of ion occupancy of each binding site, $B_{1}$ site is empty: $P\left(\mathrm{~B}_{1}\right) ; \mathrm{B}_{1}$ site binds $\mathrm{K}^{+}: P\left(\mathrm{~B}_{1} \mathrm{~K}\right) ; \mathrm{B}_{2}$ site is empty: $P\left(\mathrm{~B}_{2}\right)$; and $\mathrm{B}_{2}$ site binds $\mathrm{K}^{+}: P\left(\mathrm{~B}_{2} \mathrm{~K}\right)$. We postulate that the probability of $\mathrm{B}_{1}$ site condition is independent of the probability of $\mathrm{B}_{2}$ site condition and vice versa. This means that the presence of $\mathrm{K}^{+}$at $\mathrm{B}_{1}$ site does not influence the presence of $\mathrm{K}^{+}$at $\mathrm{B}_{2}$ site. We also postulate that rate constants are not affected by the appearance of the $\mathrm{K}^{+}$ion at the neighboring binding site. This model under these postulations adequately describes experimental data.

$$
P\left(\mathrm{~B}_{1}, \mathrm{~B}_{2}\right)=P\left(\mathrm{~B}_{1}\right) P\left(\mathrm{~B}_{2}\right)
$$




$$
\begin{gathered}
P\left(\mathrm{~B}_{1}, \mathrm{~B}_{2} \mathrm{~K}\right)=P\left(\mathrm{~B}_{1}\right) P\left(\mathrm{~B}_{2} \mathrm{~K}\right) \\
P\left(\mathrm{~B}_{1} \mathrm{~K}, \mathrm{~B}_{2}\right)=P\left(\mathrm{~B}_{1} \mathrm{~K}\right) P\left(\mathrm{~B}_{2}\right) \\
P\left(\mathrm{~B}_{1} \mathrm{~K}, \mathrm{~B}_{2} \mathrm{~K}\right)=P\left(\mathrm{~B}_{1} \mathrm{~K}\right) P\left(\mathrm{~B}_{2} \mathrm{~K}\right)
\end{gathered}
$$

where $P\left(\mathrm{~B}_{1}\right)+P\left(\mathrm{~B}_{1} \mathrm{~K}\right)=1, \quad P\left(\mathrm{~B}_{2}\right)+P\left(\mathrm{~B}_{2} \mathrm{~K}\right)=1, \quad$ and $P\left(\mathrm{~B}_{1}, \mathrm{~B}_{2}\right)+P\left(\mathrm{~B}_{1}, \mathrm{~B}_{2} \mathrm{~K}\right)+P\left(\mathrm{~B}_{1} \mathrm{~K}, \mathrm{~B}_{2}\right)+P\left(\mathrm{~B}_{1} \mathrm{~K}, \mathrm{~B}_{2} \mathrm{~K}\right)=1$.

Potassium ion flux in $\mathrm{K}^{+}$solution. The potassium ion flux between $B_{1}$ site and $B_{2}$ site is calculated as follows:

$$
I_{\mathrm{K}(\mathrm{i})} / e=P\left(\mathrm{~B}_{1}, \mathrm{~B}_{2} \mathrm{~K}\right) k_{\mathrm{K}-2}-P\left(\mathrm{~B}_{1} \mathrm{~K}, \mathrm{~B}_{2}\right) k_{\mathrm{K} 2}
$$

where $I_{\mathrm{K}(\mathrm{i})}$ represents $\mathrm{K}^{+}$current between $\mathrm{B}_{1}$ and $\mathrm{B}_{2}$ site and $e$ is elementary charge, $1.6 \times 10^{-19} \mathrm{C}$.

Then,

$$
P\left(\mathrm{~B}_{1} \mathrm{~K}, \mathrm{~B}_{2}\right)\left(k_{\mathrm{K} 2} / k_{\mathrm{K}-2}\right)=P\left(\mathrm{~B}_{1}, \mathrm{~B}_{2} \mathrm{~K}\right)-\left(I_{\mathrm{K}(\mathrm{i})} / e\right) / k_{\mathrm{K}-2}
$$

When $k_{\mathrm{K}-2} \gg I_{\mathrm{K}(\mathrm{i})} / e,\left(I_{\mathrm{K}(\mathrm{i})} / e\right) / k_{\mathrm{K}-2}$ becomes nearly 0 . Then,

$$
\begin{aligned}
& P\left(\mathrm{~B}_{1} \mathrm{~K}, \mathrm{~B}_{2}\right)\left(k_{\mathrm{K} 2} / k_{\mathrm{K}-2}\right)=P\left(\mathrm{~B}_{1}, \mathrm{~B}_{2} \mathrm{~K}\right) \\
k_{\mathrm{K} 2} / k_{\mathrm{K}-2}= & P\left(\mathrm{~B}_{1}, \mathrm{~B}_{2} \mathrm{~K}\right) / P\left(\mathrm{~B}_{1} \mathrm{~K}, \mathrm{~B}_{2}\right) \\
= & \left\{P\left(\mathrm{~B}_{2} \mathrm{~K}\right)\left(1-P\left(\mathrm{~B}_{1} \mathrm{~K}\right)\right)\right\} /\left\{P\left(\mathrm{~B}_{1} \mathrm{~K}\right)\left(1-P\left(\mathrm{~B}_{2} \mathrm{~K}\right)\right)\right\} \\
= & \exp \left[F\left(1-\delta_{1}-\delta_{2}\right)(-V) / R T\right]=\exp (\mathrm{i})
\end{aligned}
$$

This is the fast equilibrium condition. We also postulate that the $\mathrm{K}^{+}$ion can bind to the binding site only when that site is empty. That is, there is no knock-on mechanism between $\mathrm{K}^{+}$ions. $\mathrm{K}^{+}$ion flux between the outside of the membrane and the $\mathrm{B}_{1}$ site $\left(I_{\mathrm{K}(1)} / e\right)$ is described as follows.

$$
\begin{aligned}
I_{\mathrm{K}(1)} / e & =P\left(\mathrm{~B}_{1} \mathrm{~K}\right) k_{\mathrm{K}-1}-\left[\mathrm{K}^{+}\right]_{\mathrm{o}} k_{\mathrm{K} 1} P\left(\mathrm{~B}_{1}\right) \\
& =P\left(\mathrm{~B}_{1} \mathrm{~K}\right) k_{\mathrm{K}-1}-\left[\mathrm{K}^{+}\right]_{\mathrm{o}} k_{\mathrm{K} 1}\left(1-P\left(\mathrm{~B}_{1} \mathrm{~K}\right)\right)
\end{aligned}
$$

where $\left[\mathrm{K}^{+}\right]_{\mathrm{o}}$ indicates potassium ion concentration of the outside of the membrane. On the other hand, the $\mathrm{K}^{+}$ion flux between $\mathrm{B}_{2}$ site and the inside of the membrane $\left(I_{\mathrm{K}(2)} / e\right)$ is described as follows.

$$
\begin{aligned}
I_{\mathrm{K}(2)} / e & =\left[\mathrm{K}^{+}\right]_{\mathrm{i}} k_{\mathrm{K}-3} P\left(\mathrm{~B}_{2}\right)-P\left(\mathrm{~B}_{2} \mathrm{~K}\right) k_{\mathrm{K} 3} \\
& =\left[\mathrm{K}^{+}\right]_{\mathrm{i}} k_{\mathrm{K}-3}\left(1-P\left(\mathrm{~B}_{2} \mathrm{~K}\right)\right)-P\left(\mathrm{~B}_{2} \mathrm{~K}\right) k_{\mathrm{K} 3}
\end{aligned}
$$

where $\left[\mathrm{K}^{+}\right]_{\mathrm{i}}$ indicates the potassium ion concentration on the inside of the membrane.

In the cation channel from Tetrahymena cilia, we obtained the values of the single potassium current, $4.43 \mathrm{pA}$ in $16.3 \mathrm{mM} \mathrm{K}^{+}$, and $8.85 \mathrm{pA}$ in $1 \mathrm{M} \mathrm{K}^{+}$, in both sides of the membrane at $+25 \mathrm{mV}$ [30]. From these values and by using the equality " $I_{\mathrm{K}(1)}=I_{\mathrm{K}(2)}=$ $I_{\mathrm{K}}$," we have obtained the values of $k_{\mathrm{Kf}}$ and $k_{\mathrm{Kb}}$, and from these two values we have calculated four rate constants of $\mathrm{K}^{+}, k_{\mathrm{K} 1}, k_{\mathrm{K}-3}, k_{\mathrm{K}-1}$, and $k_{\mathrm{K} 3}$ at $+25 \mathrm{mV}$. In these calculations we postulate $0.1,0.2,0.3$, and 0.4

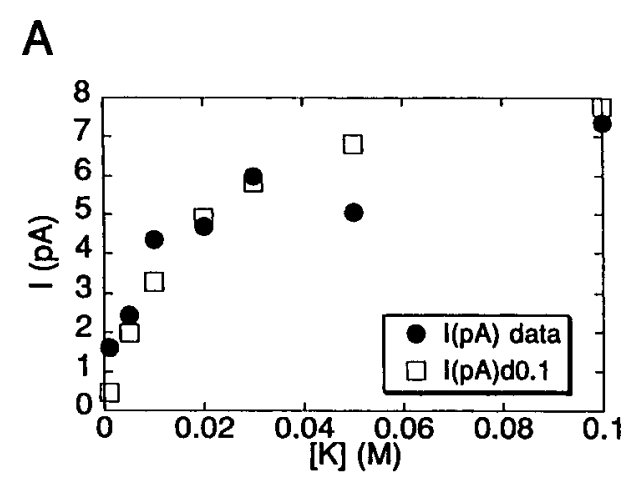

B

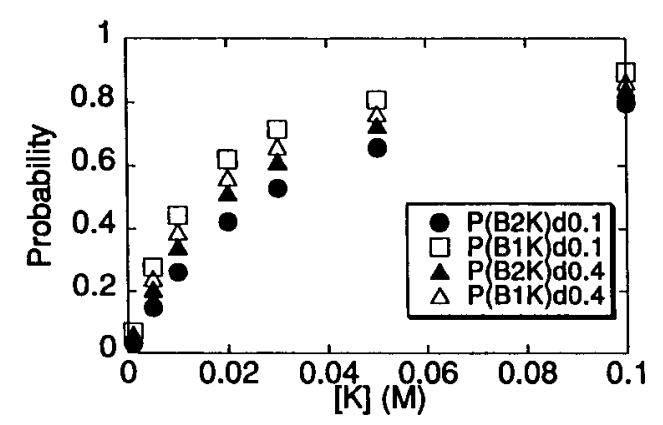

Fig. 2. (A) Concentration dependency of single channel currents at symmetric $\mathrm{K}^{+}$solution at $\mathbf{+ 2 5} \mathrm{mV}$. The closed circles indicate data of the cation channels from Tetrahymena cilia [30]. The values of single channel currents calculated for $\delta$ is $0.1(\square)$. (B) Probabilities of ion occupancy of two binding sites at various symmetric $\mathbf{K}^{+}$concentrations. Membrane voltage is $+25 \mathrm{mV}$. $P\left(\mathrm{~B}_{2} \mathrm{~K}\right)$ : $\delta=0.1(\bullet), \delta=0.4(\mathbf{\Delta}) . P\left(\mathrm{~B}_{1} \mathrm{~K}\right): \delta=0.1(\square), \delta=0.4(\triangle)$. The values of probabilities when $\delta$ is 0.2 or 0.3 are between $\delta$ are 0.1 and 0.4 .

for the values of $\delta$ and 0.5 for the value of $\varepsilon$. As the values of $\delta$ increase, the value of $k_{\mathrm{Kf}}$ slightly decreases and the value of $k_{\mathrm{Kb}}$ slightly increases. The four rate constants also slightly change as the value of $\delta$ changes. However, the dependence of the four rate constants on $\delta$ is small.

$I_{K}-\left[\mathrm{K}^{+}\right]$relation of the channel. If we obtain the four rate constants, we can calculate the ionic currents from the values of ionic concentrations in both sides of the membrane.

We compare the potassium concentration dependency of single channel currents obtained from experiments [30] with that obtained by calculations by using this model at $+25 \mathrm{mV}$ in symmetric $\mathrm{K}^{+}$solution (Fig. 2A). In calculations, the values of the single channel currents are very similar even where the value of $\delta$ changes. The single-file two-site model can explain this data well (Fig. 2A).

Figure $2 \mathrm{~B}$ shows $P\left(\mathrm{~B}_{1} \mathrm{~K}\right)$ and $P\left(\mathrm{~B}_{2} \mathrm{~K}\right)$ in various concentrations of symmetric $\mathrm{K}^{+}$solution when $\delta$ is 0.1 or 0.4 . The values of $P\left(\mathrm{~B}_{1} \mathrm{~K}\right)$ and $P\left(\mathrm{~B}_{2} \mathrm{~K}\right)$ depend 
on the value of $\delta$. The ratio of $P\left(\mathrm{~B}_{1} \mathrm{~K}\right)$ and $P\left(\mathrm{~B}_{2} \mathrm{~K}\right)$ is dependent on the $\mathrm{K}^{+}$concentrations, and both $P\left(\mathrm{~B}_{1} \mathrm{~K}\right)$ and $P\left(\mathrm{~B}_{2} \mathrm{~K}\right)$ increase when the $\mathrm{K}^{+}$concentration increases, becoming close to one but never decreasing.

\section{Calcium ion flux in $\mathrm{Ca}^{2+}$ solution}

Only one calcium ion can bind to one of the binding sites and this ion binds to $\mathrm{B}_{1}$ site or $\mathrm{B}_{2}$ site. This means,

$$
P\left(\mathrm{~B}_{1} \mathrm{CaB}_{2}\right)=P\left(\mathrm{~B}_{1} \mathrm{CaB}_{2}\right)_{\mathrm{B} 1}+P\left(\mathrm{~B}_{1} \mathrm{CaB}_{2}\right)_{\mathrm{B} 2}
$$

where $P\left(\mathrm{~B}_{1} \mathrm{CaB}_{2}\right)_{\mathrm{B} 1}$ and $P\left(\mathrm{~B}_{1} \mathrm{CaB}_{2}\right)_{\mathrm{B} 2}$ indicate the probabilities that the calcium ion binds to $B_{1}$ site or $\mathrm{B}_{2}$ site, respectively. The ratio of $P\left(\mathrm{~B}_{1} \mathrm{CaB}_{2}\right)_{\mathrm{B} 1}$ and $P\left(\mathrm{~B}_{1} \mathrm{CaB}_{2}\right)_{\mathrm{B} 2}$ is decided by two rate constants, $k_{\mathrm{Ca} 2}$ and $k_{\mathrm{Ca}-2}$, because we postulate a fast equilibrium condition between $\mathrm{B}_{1}$ site and $\mathrm{B}_{2}$ site for the $\mathrm{Ca}^{2+}$ ion.

$$
\begin{aligned}
P\left(\mathrm{~B}_{1} \mathrm{CaB}_{2}\right)_{\mathrm{B} 1} k_{\mathrm{Ca} 2}= & P\left(\mathrm{~B}_{1} \mathrm{CaB}_{2}\right)_{\mathrm{B} 2} k_{\mathrm{Ca}-2} \\
P\left(\mathrm{~B}_{1} \mathrm{CaB}_{2}\right)_{\mathrm{B} 1} / P\left(\mathrm{~B}_{1} \mathrm{CaB}_{2}\right)_{\mathrm{B} 2} & =k_{\mathrm{Ca}-2} / k_{\mathrm{Ca} 2} \\
& =\exp \left(2 F\left(1-\delta_{1}-\delta_{2}\right) V / R T\right) \\
& =\exp (\mathrm{r})
\end{aligned}
$$

The calcium ion flux is calculated between the extracellular side of the membrane and $\mathrm{B}_{1}$ site $\left(: I_{\mathrm{Ca}(1)} / e\right)$ and between $\mathrm{B}_{2}$ site and the intracellular side of the membrane $\left(: I_{\mathrm{Ca}(2)} / e\right)$.

$$
\begin{aligned}
I_{\mathrm{Ca}(1)} / e= & 2\left\{P\left(\mathrm{~B}_{1} \mathrm{CaB}_{2}\right)_{\mathrm{B} 1} k_{\mathrm{Ca}-1}-\left[\mathrm{Ca}^{2+}\right]_{\mathrm{o}} P\left(\mathrm{~B}_{1}, \mathrm{~B}_{2}\right) k_{\mathrm{Ca} 1}\right\} \\
= & 2 P\left(\mathrm{~B}_{1} \mathrm{CaB}_{2}\right)\left\{k_{\mathrm{Ca}-1} \exp (\mathrm{r}) /(1+\exp (\mathrm{r}))\right. \\
& \left.+\left[\mathrm{Ca}^{2+}\right]_{\mathrm{o}} k_{\mathrm{Ca} 1}\right\}-2\left[\mathrm{Ca}^{2+}\right]_{\mathrm{o}} k_{\mathrm{Ca} 1} \\
I_{\mathrm{Ca}(2)} / e= & 2\left\{\left[\mathrm{Ca}^{2+}\right]_{\mathrm{i}} P\left(\mathrm{~B}_{1}, \mathrm{~B}_{2}\right) k_{\mathrm{Ca}-3}-P\left(\mathrm{~B}_{1} \mathrm{CaB}_{2}\right)_{\mathrm{B} 2} k_{\mathrm{Ca} 3}\right\} \\
= & 2\left[\mathrm{Ca}^{2+}\right]_{\mathrm{i}} k_{\mathrm{Ca}-3}-2 P\left(\mathrm{~B}_{1} \mathrm{CaB}_{2}\right)\left\{k_{\mathrm{Ca} 3} /(1+\exp (\mathrm{r}))\right. \\
& \left.+\left[\mathrm{Ca}^{2+}\right]_{\mathrm{i}} k_{\mathrm{Ca}-3}\right\}
\end{aligned}
$$

$I_{\mathrm{Ca}(1)} / e$ equals $I_{\mathrm{Ca}(2)} / e$. Then, when $\left[\mathrm{Ca}^{2+}\right]_{\mathrm{o}}=\left[\mathrm{Ca}^{2+}\right]_{\mathrm{i}}=$ $\left[\mathrm{Ca}^{2+}\right]$, we obtain the Michaelis-Menten type equation.

$$
\begin{aligned}
& I_{\mathrm{Ca}} / e \\
& =\frac{2\left(k_{\mathrm{Ca}-1} k_{\mathrm{Ca}-3} \exp (\mathrm{r})-k_{\mathrm{Ca} 1} k_{\mathrm{Ca} 3}\right)}{\left(k_{\mathrm{Ca} 1}+k_{\mathrm{Ca}-3}\right)\{1+\exp (\mathrm{r})\}+\left\{k_{\mathrm{Ca} 3}+k_{\mathrm{Ca}-1} \exp (\mathrm{r})\right\} /\left[\mathrm{Ca}^{2+}\right]}
\end{aligned}
$$

$I_{\mathrm{Ca}} / e$ indicates the calcium ion flux through the channel.

According to the previous data, the maximum calcium current at $+25 \mathrm{mV}$ is $0.5 \mathrm{pA}$ [30]. Assuming that the apparent Michaelis constant is $0.05,0.1$, or $0.2 \mathrm{mM}$, we obtained values of $k_{\text {Caf }}$ and $k_{\text {Cab }}$. From these two values we calculated four rate constants of $\mathrm{Ca}^{2+}$ at $+25 \mathrm{mV}, k_{\mathrm{Ca} 1}, k_{\mathrm{Ca}-3}, k_{\mathrm{Ca}-1}$, and $k_{\mathrm{Ca} 3}$. In these calculations we postulate $0.1,0.2,0.3$, and 0.4 for the values of $\delta$ and 0.5 for the value of $\varepsilon$. As the values of $\delta$ increase the values of $k_{\text {Caf }}$ decrease and the values of
$k_{\mathrm{Cab}}$ increase. The four rate constants also change as the value of $\delta$ changes, but the changes are small.

\section{Ion flux in mixed solution of $\mathrm{K}^{+}$and $\mathrm{Ca}^{2+}$ Probabilities of ion occupancy of binding}

sites. The probabilities of ion occupancy of binding sites are described as follows. It is assumed that there is no possibility that two sites bind two $\mathrm{Ca}^{2+}$ simultaneously or that one site binds $\mathrm{Ca}^{2+}$ and the other binds $\mathrm{K}^{+}$.

$$
\begin{aligned}
P\left(\mathrm{~B}_{1}, \mathrm{~B}_{2}\right) & =P\left(\mathrm{~B}_{1}\right)\left[P\left(\mathrm{~B}_{2}\right) /\left\{P\left(\mathrm{~B}_{2}\right)+P\left(\mathrm{~B}_{2} \mathrm{~K}\right)\right\}\right] \\
& =P\left(\mathrm{~B}_{2}\right)\left[P\left(\mathrm{~B}_{1}\right) /\left\{P\left(\mathrm{~B}_{1}\right)+P\left(\mathrm{~B}_{1} \mathrm{~K}\right)\right\}\right] \\
& =P\left(\mathrm{~B}_{1}\right) P\left(\mathrm{~B}_{2}\right) /\left\{1-P\left(\mathrm{~B}_{1} \mathrm{CaB}_{2}\right)\right\} \\
& \\
P\left(\mathrm{~B}_{1}, \mathrm{~B}_{2} \mathrm{~K}\right) & =P\left(\mathrm{~B}_{1}\right) P\left(\mathrm{~B}_{2} \mathrm{~K}\right) /\left\{1-P\left(\mathrm{~B}_{1} \mathrm{CaB}_{2}\right)\right\} \\
P\left(\mathrm{~B}_{1} \mathrm{~K}, \mathrm{~B}_{2}\right) & =P\left(\mathrm{~B}_{1} \mathrm{~K}\right) P\left(\mathrm{~B}_{2}\right) /\left\{1-P\left(\mathrm{~B}_{1} \mathrm{CaB}_{2}\right)\right\} \\
P\left(\mathrm{~B}_{1} \mathrm{~K}, \mathrm{~B}_{2} \mathrm{~K}\right) & =P\left(\mathrm{~B}_{1} \mathrm{~K}\right) P\left(\mathrm{~B}_{2} \mathrm{~K}\right) /\left\{1-P\left(\mathrm{~B}_{1} \mathrm{CaB}_{2}\right)\right\}
\end{aligned}
$$

where $P\left(\mathrm{~B}_{1}\right)+P\left(\mathrm{~B}_{1} \mathrm{~K}\right)+P\left(\mathrm{~B}_{1} \mathrm{CaB}_{2}\right)=1, P\left(\mathrm{~B}_{2}\right)+P\left(\mathrm{~B}_{2} \mathrm{~K}\right)+$ $P\left(\mathrm{~B}_{1} \mathrm{CaB}_{2}\right)=1$, and $P\left(\mathrm{~B}_{1}, \mathrm{~B}_{2}\right)+P\left(\mathrm{~B}_{1}, \mathrm{~B}_{2} \mathrm{~K}\right)+P\left(\mathrm{~B}_{1} \mathrm{~K}, \mathrm{~B}_{2}\right)+$ $P\left(\mathrm{~B}_{1} \mathrm{~K}, \mathrm{~B}_{2} \mathrm{~K}\right)+P\left(\mathrm{~B}_{1} \mathrm{CaB}_{2}\right)=1$. The potassium ions between $\mathrm{B}_{1}$ and $\mathrm{B}_{2}$ satisfy the fast equilibrium condition (Eq. 13).

Then,

$$
\begin{aligned}
\frac{k_{\mathrm{K} 2}}{k_{\mathrm{K}-2}} & =\frac{P\left(\mathrm{~B}_{2} \mathrm{~K}\right)\left\{1-P\left(\mathrm{~B}_{1} \mathrm{~K}\right)-P\left(\mathrm{~B}_{1} \mathrm{CaB}_{2}\right)\right\}}{P\left(\mathrm{~B}_{1} \mathrm{~K}\right)\left\{1-P\left(\mathrm{~B}_{2} \mathrm{~K}\right)-P\left(\mathrm{~B}_{1} \mathrm{CaB}_{2}\right)\right\}} \\
& =\exp \left[F\left(1-\delta_{1}-\delta_{2}\right)(-V) / R T\right]=\exp (\mathrm{i})
\end{aligned}
$$

From Eq. 27,

$$
\begin{aligned}
& P\left(\mathrm{~B}_{1} \mathrm{CaB}_{2}\right) \\
& \quad=\frac{P\left(\mathrm{~B}_{1} \mathrm{~K}\right)\left\{P\left(\mathrm{~B}_{2} \mathrm{~K}\right)(1-\exp (\mathrm{i}))+\exp (\mathrm{i})\right\}-P\left(\mathrm{~B}_{2} \mathrm{~K}\right)}{P\left(\mathrm{~B}_{1} \mathrm{~K}\right) \exp (\mathrm{i})-P\left(\mathrm{~B}_{2} \mathrm{~K}\right)}
\end{aligned}
$$

In calcium ion binding, we postulate that the calcium ion can bind to the nearer binding site only when that site is empty and the far site does not bind a calcium ion. For example, an extracellular calcium ion can bind to $B_{1}$ site only when $B_{1}$ site is empty, and intracellular calcium ion can bind to $B_{2}$ site only when $\mathrm{B}_{2}$ site is empty. Concerning the condition of the other site, there are three cases. (1) The calcium ion can bind to the binding site only when both binding sites are empty $\left(h_{1}=h_{2}=0\right)$. " $h_{1}$ " and " $h_{2}$ " are the parameters that give the contribution to the $\mathrm{K}^{+}$ion flux of bound $\mathrm{K}^{+}$in the neighboring site driven out by $\mathrm{Ca}^{2+}$ binding (see Eqs. 29 and 30). (2) The calcium ion can bind to the binding site even when the far site binds a potassium ion, and then that potassium ion is pushed off by the calcium ion, and the rate constant of cal- 
cium binding is the same as when both binding sites are empty $\left(h_{1}=h_{2}=1\right)$. (3) The calcium ion can bind to the binding site even when the far site binds a potassium ion, and then that potassium ion is pushed off by the calcium ion, but the rate constant of calcium binding becomes smaller than when both binding sites are empty $\left(0<h_{1}<1,0<h_{2}<1\right)$. Again we emphasize that two calcium ions cannot bind to the two binding sites simultaneously, nor can one calcium ion and one potassium ion bind to the two sites simultaneously. We investigated these three cases, trying to determine which one is suitable for the Tetrahymena cation channel.

$\mathrm{K}^{+}$ion flux and $\mathrm{Ca}^{2+}$ ion flux in mixed solution of $\mathrm{K}^{+}$and $\mathrm{Ca}^{2+}$. The calculations of the $\mathrm{K}^{+}$ ion flux, $\mathrm{Ca}^{2+}$ ion flux, and occupation probabilities can be performed straightforwardly. The $\mathrm{K}^{+}$ion flux between $\mathrm{B}_{1}$ site and the extracellular side of the membrane is

$$
\begin{aligned}
I_{\mathrm{K}(1)} / e= & k_{\mathrm{K}-1}\left\{P\left(\mathrm{~B}_{1} \mathrm{~K}, \mathrm{~B}_{2}\right)+P\left(\mathrm{~B}_{1} \mathrm{~K}, \mathrm{~B}_{2} \mathrm{~K}\right)\right\} \\
& +\left[\mathrm{Ca}^{2+}\right]_{\mathrm{i}} h_{2} k_{\mathrm{Ca}-3} P\left(\mathrm{~B}_{1} \mathrm{~K}, \mathrm{~B}_{2}\right) \\
& -\left[\mathrm{K}^{+}\right]_{\mathrm{o}} k_{\mathrm{K} 1}\left\{P\left(\mathrm{~B}_{1}, \mathrm{~B}_{2}\right)+P\left(\mathrm{~B}_{1}, \mathrm{~B}_{2} \mathrm{~K}\right)\right\}
\end{aligned}
$$

The $\mathrm{K}^{+}$ion flux between $\mathrm{B}_{2}$ site and the intracellular side of the membrane is

$$
\begin{aligned}
I_{\mathrm{K}(2)} / e= & {\left[\mathrm{K}^{+}\right]_{\mathrm{i}} k_{\mathrm{K}-3}\left\{P\left(\mathrm{~B}_{1}, \mathrm{~B}_{2}\right)+P\left(\mathrm{~B}_{1} \mathrm{~K}, \mathrm{~B}_{2}\right)\right\} } \\
& -k_{\mathrm{K} 3}\left\{P\left(\mathrm{~B}_{1}, \mathrm{~B}_{2} \mathrm{~K}\right)+P\left(\mathrm{~B}_{1} \mathrm{~K}, \mathrm{~B}_{2} \mathrm{~K}\right)\right\} \\
& -\left[\mathrm{Ca}^{2+}\right]_{\mathrm{o}} h_{1} k_{\mathrm{Ca} 1} P\left(\mathrm{~B}_{1}, \mathrm{~B}_{2} \mathrm{~K}\right)
\end{aligned}
$$

where, $0 \leqq h_{1} \leqq 1$ and $0 \leqq h_{2} \leqq 1$. " $\left[\mathrm{Ca}^{2+}\right]_{\mathrm{i}} h_{2} k_{\mathrm{Ca}-3} P\left(\mathrm{~B}_{1} \mathrm{~K}\right.$, $\left.\mathrm{B}_{2}\right)$ " and " $\left[\mathrm{Ca}^{2+}\right]_{0} h_{1} k_{\mathrm{Cal}} P\left(\mathrm{~B}_{1}, \mathrm{~B}_{2} \mathrm{~K}\right)$ " are the $\mathrm{K}^{+}$ion flux by the bound $\mathrm{K}^{+}$ion that is pushed off by calcium binding. When $h_{1}=h_{2}=0$, it is the first case, and when $h_{1}=h_{2}=1$, it is the second case; when $0<h_{1}<1$ and $0<h_{2}<1$, it is the third case.

$\mathrm{Ca}^{2+}$ ion flux is calculated between the extracellular side of the membrane and $\mathrm{B}_{1}$ site $\left(: I_{\mathrm{Ca}(1)} / e\right)$ and between $\mathrm{B}_{2}$ site and the intracellular side of the membrane $\left(: I_{\mathrm{Ca}(2)} / e\right)$.

$$
\begin{aligned}
I_{\mathrm{Ca}(1)} / e= & 2\left\{P\left(\mathrm{~B}_{1} \mathrm{CaB}_{2}\right)_{\mathrm{B} 1} k_{\mathrm{Ca}-1}-\left[\mathrm{Ca}^{2+}\right]_{\mathrm{o}}\left(P\left(\mathrm{~B}_{1}, \mathrm{~B}_{2}\right) k_{\mathrm{Ca} 1}\right.\right. \\
& \left.\left.+P\left(\mathrm{~B}_{1}, \mathrm{~B}_{2} \mathrm{~K}\right) h_{1} k_{\mathrm{Ca} 1}\right)\right\} \\
= & 2 P\left(\mathrm{~B}_{1} \mathrm{CaB}_{2}\right) \exp (\mathrm{r}) k_{\mathrm{Ca}-1} /(1+\exp (\mathrm{r})) \\
& -2\left[\mathrm{Ca}^{2+}\right]_{\mathrm{o}}\left\{P\left(\mathrm{~B}_{1}\right) P\left(\mathrm{~B}_{2}\right) k_{\mathrm{Ca} 1} /\left(1-P\left(\mathrm{~B}_{1} \mathrm{CaB}_{2}\right)\right)\right. \\
& \left.+P\left(\mathrm{~B}_{1}\right) P\left(\mathrm{~B}_{2} \mathrm{~K}\right) h_{1} k_{\mathrm{Ca} 1} /\left(1-P\left(\mathrm{~B}_{1} \mathrm{CaB}_{2}\right)\right)\right\}
\end{aligned}
$$

$$
\begin{aligned}
I_{\mathrm{Ca}(2)} / e= & 2\left\{[ \mathrm { Ca } ^ { 2 + } ] _ { \mathrm { i } } \left(P\left(\mathrm{~B}_{1}, \mathrm{~B}_{2}\right) k_{\mathrm{Ca}-3}\right.\right. \\
& \left.\left.+P\left(\mathrm{~B}_{1} \mathrm{~K}, \mathrm{~B}_{2}\right) h_{2} k_{\mathrm{Ca}-3}\right)-P\left(\mathrm{~B}_{1} \mathrm{CaB}_{2}\right)_{\mathrm{B} 2} k_{\mathrm{Ca} 3}\right\} \\
= & 2\left[\mathrm{Ca}^{2+}\right]_{\mathrm{i}}\left\{P\left(\mathrm{~B}_{1}\right) P\left(\mathrm{~B}_{2}\right) k_{\mathrm{Ca}-3} /\left(1-P\left(\mathrm{~B}_{1} \mathrm{CaB}_{2}\right)\right)\right. \\
& \left.+P\left(\mathrm{~B}_{1} \mathrm{~K}\right) P\left(\mathrm{~B}_{2}\right) h_{2} k_{\mathrm{Ca}-3} /\left(1-P\left(\mathrm{~B}_{1} \mathrm{CaB}_{2}\right)\right)\right\} \\
& -2 P\left(\mathrm{~B}_{1} \mathrm{CaB}_{2}\right) k_{\mathrm{Ca} 3} /(1+\exp (\mathrm{r}))
\end{aligned}
$$

where, $0 \leqq h_{1} \leqq 1,0 \leqq h_{2} \leqq 1$. In all conditions $\mathrm{Ca}^{2+}$ ion can bind to the nearer site only when that site is empty and the far site does not bind a calcium ion.

Using the relationships $I_{\mathrm{K}(1)}=I_{\mathrm{K}(2)}$ and $I_{\mathrm{Ca}(1)}=I_{\mathrm{Ca}(2)}$, we can calculate the probabilities of ion occupancy of the binding sites. When the value of $P\left(\mathrm{~B}_{2} \mathrm{~K}\right)$ is obtained, $P\left(\mathrm{~B}_{1} \mathrm{~K}\right)$ and $P\left(\mathrm{~B}_{1} \mathrm{CaB}_{2}\right)$ are calculated. When the values of $P\left(\mathrm{~B}_{1} \mathrm{~K}\right), P\left(\mathrm{~B}_{2} \mathrm{~K}\right)$, and $P\left(\mathrm{~B}_{1} \mathrm{CaB}_{2}\right)$ are obtained, the ionic currents of $\mathrm{K}^{+}$and $\mathrm{Ca}^{2+}$ are calculated.

Comparison of the values of the currents obtained by the calculations and by the experiments. We can now calculate the ion flux from rate constants, ionic concentrations, and the values of $h_{1}$ and $h_{2}$. Rate constants are calculated by the voltage-independent elements of the constants and the membrane voltage.

In the following calculations, we assume the condition $\varepsilon=0.5$. Since the single channel currents of the channel from Tetrahymena cilia were obtained when membrane voltage was $+25 \mathrm{mV}[25,30]$, we use $+25 \mathrm{mV}$ as the membrane voltage in the calculation. We use $0.5 \mathrm{pA}$ as the value of maximum calcium current at $+25 \mathrm{mV}$ [25], change the values of the apparent Michaelis constant of $\mathrm{Ca}^{2+}\left(K_{\mathrm{Ca}}\right)$, and then try to fit the data. Calculated currents at $+25 \mathrm{mV}$ are similar whenever the value of $\delta$ is changed between 0.1 and 0.4 .

At first we postulate the following condition,

$$
h_{1}=h_{2}=1
$$

Figure 3 shows the data obtained in the experiments and the calculations. We tested $0.1,0.2$, and $0.5 \mathrm{mM}$ as the value of $K_{\mathrm{Ca}}$. In the condition where $\left[\mathrm{K}^{+}\right]+2\left[\mathrm{Ca}^{2+}\right]=100 \mathrm{mM}$, the calculated currents when $K_{\mathrm{Ca}}$ is $0.5 \mathrm{mM}$ are close to the experimental data. In the condition where $\left[\mathrm{K}^{+}\right]+2\left[\mathrm{Ca}^{2+}\right]=30 \mathrm{mM}$, the calculated currents when $K_{\mathrm{Ca}}$ is $0.2 \mathrm{mM}$ are close to the experimental data. In the condition where $\left[\mathrm{K}^{+}\right]+2\left[\mathrm{Ca}^{2+}\right]=10 \mathrm{mM}$, the calculated currents when $K_{\mathrm{Ca}}$ is $0.1 \mathrm{mM}$ are close to the experimental data. There is no value of $K_{\mathrm{Ca}}$ that can agree with all the experimental data. This fact means the condition " $h_{1}=h_{2}=1$ " cannot explain all the data.

Next we postulate the following condition,

$$
h_{1}=h_{2}=0
$$

Figure 4 shows the data obtained in the experiments and the calculations. We test $0.05,0.1$, and $0.2 \mathrm{mM}$ as the value of $K_{\mathrm{Ca}}$. In this condition the calculated currents with $0.1 \mathrm{mM}$ as the value of $K_{\mathrm{Ca}}$ are similar to all the experimental data (Fig. 4). We consider that the condition " $h_{1}=h_{2}=0$ " can explain all the data. This means that the Tetrahymena cation channel can bind 
A

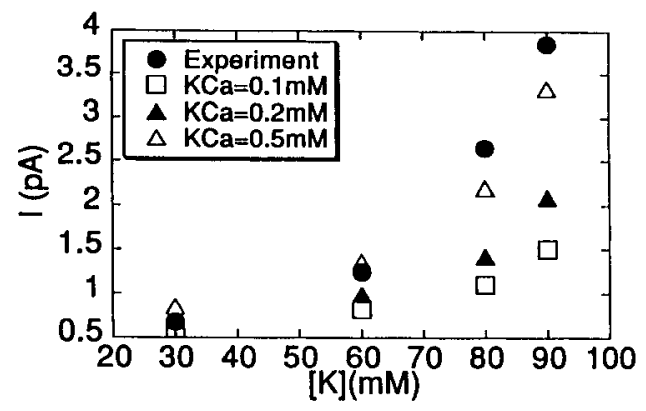

B

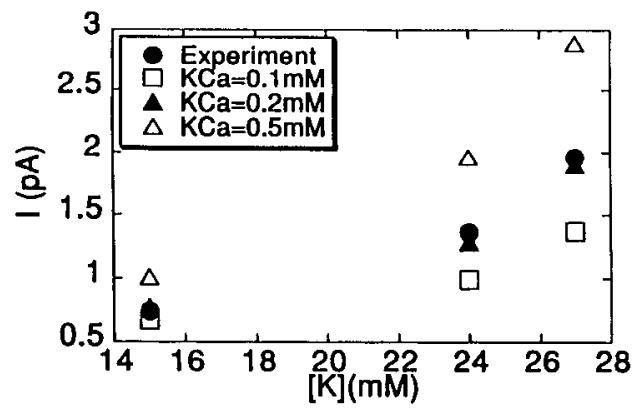

C

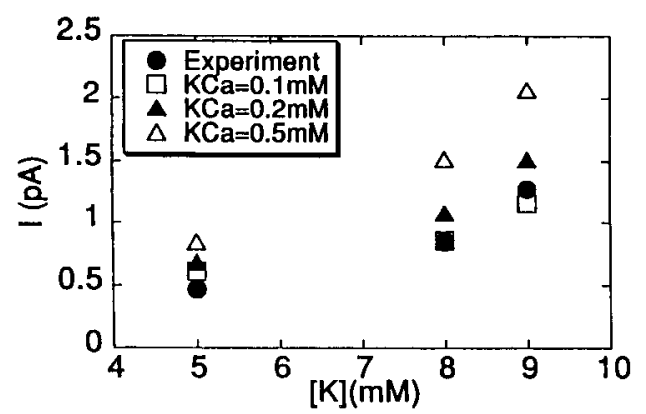

Fig. 3. Single channel currents in mixed symmetrical solutions of $\mathbf{K}^{+}$and $\mathbf{C a}^{2+}$. In calculations, one was used as the values of $h_{1}$ and $h_{2}$. $\delta=0.1$. Membrane voltage is $+25 \mathrm{mV}$. Data obtained by experiment (-). Other symbols are determined by calculations under the following conditions: $K_{\mathrm{Ca}}=0.1 \mathrm{mM}(\square), K_{\mathrm{Ca}}=0.2 \mathrm{mM}(\boldsymbol{\Delta}), K_{\mathrm{Ca}}=0.5 \mathrm{mM}(\triangle)$. (A) $\left[\mathrm{K}^{+}\right]+2\left[\mathrm{Ca}^{2+}\right]=100 \mathrm{mM}$. (B) $\left[\mathrm{K}^{+}\right]+2\left[\mathrm{Ca}^{2+}\right]=30 \mathrm{mM}$. (C) $\left[\mathrm{K}^{+}\right]+2\left[\mathrm{Ca}^{2+}\right]=10 \mathrm{~mm}$.

two potassium ions or one calcium ion simultaneously, and one calcium ion can bind to one of the sites only when both binding sites are empty.

Next we postulate the following condition, $h_{1}=$ $h_{2}=0.5$. We carried out a similar comparison with the experimental data. This postulation cannot explain the data well.

Reversal potentials of the channel in biionic condition of $\mathrm{K}^{+}$and $\mathrm{Ca}^{2+}$. To obtain the permeability ratio of $\mathrm{K}^{+}$and $\mathrm{Ca}^{2+}$ from the reversal potentials in the bi-ionic condition of $\mathrm{K}^{+}$and $\mathrm{Ca}^{2+}$ (for example, inside: $\mathrm{K}^{+}$solution; outside: $\mathrm{Ca}^{2+}$ solution), we usually use the Goldman-Hodgkin-Katz
A

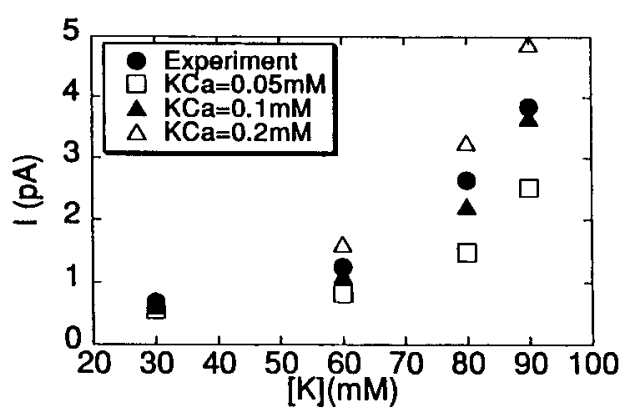

B

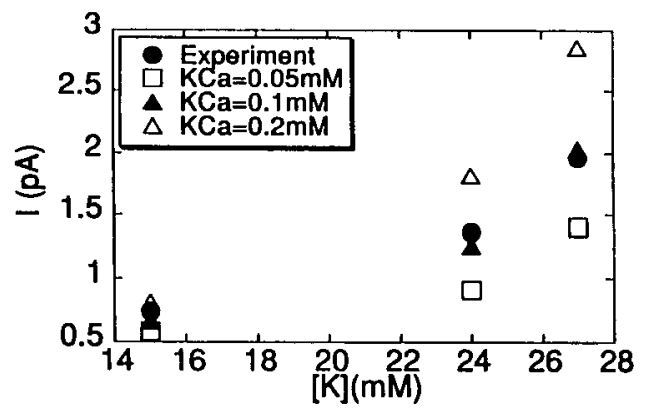

C

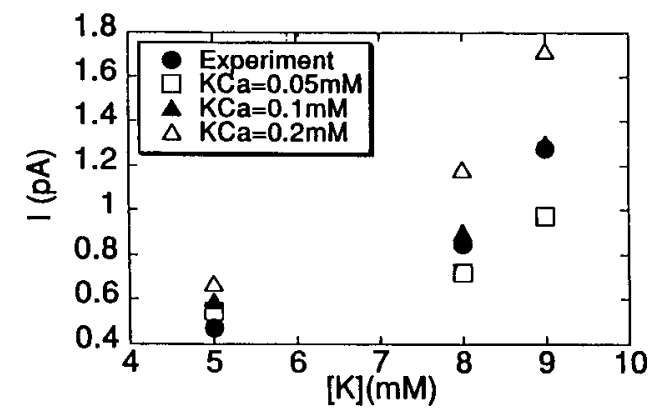

Fig. 4. Single channel currents in mixed symmetrical solutions of $\mathrm{K}^{+}$and $\mathrm{Ca}^{2+}$. In calculations, zero was used as the values of $h_{1}$ and $h_{2} . \delta=0.1$. Membrane voltage is $+25 \mathrm{mV}$. Data obtained by experiment (-). Other symbols are determined by calculations under the following conditions: $K_{\mathrm{Ca}}=0.05 \mathrm{mM}(\square), K_{\mathrm{Ca}}=0.1 \mathrm{mM}(\mathbf{\Delta}), K_{\mathrm{Ca}}=0.2 \mathrm{mM}(\triangle)$. (A) $\left[\mathrm{K}^{+}\right]+2\left[\mathrm{Ca}^{2+}\right]=100 \mathrm{~mm}$. (B) $\left[\mathrm{K}^{+}\right]+2\left[\mathrm{Ca}^{2+}\right]=30 \mathrm{~mm}$. (C) $\left[\mathrm{K}^{+}\right]+2\left[\mathrm{Ca}^{2+}\right]=10 \mathrm{mM}$.

equation. In the Goldman-Hodgkin-Katz equation, if the concentrations of $\mathrm{K}^{+}$and $\mathrm{Ca}^{2+}$ were changed while the ratio was kept constant, the reversal potentials should also remain constant. Similarly, in the single-site channel model the reversal potential is determined by rate constants and the ratio of each ion's concentrations (Fig. 5A).

In this single-file two-site model, if the concentrations of $\mathrm{K}^{+}$and $\mathrm{Ca}^{2+}$ were changed, keeping the ratio constant, the reversal potentials become different. Figure $5 \mathrm{~B}$ shows $I-V$ relations calculated by this model in the bi-ionic condition: $\left[\mathrm{K}^{+}\right]_{\mathrm{i}}=100 \mathrm{mM},\left[\mathrm{Ca}^{2+}\right]_{\mathrm{o}}=50$ $\mathrm{mM},\left[\mathrm{K}^{+}\right]_{\mathrm{o}}=\left[\mathrm{Ca}^{2+}\right]_{\mathrm{i}}=0$, and $\left[\mathrm{K}^{+}\right]_{\mathrm{i}}=10 \mathrm{mM},\left[\mathrm{Ca}^{2+}\right]_{\mathrm{o}}=$ 
A

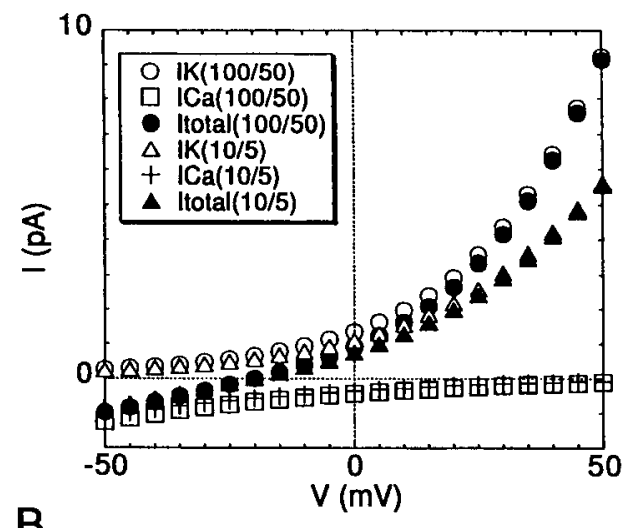

B

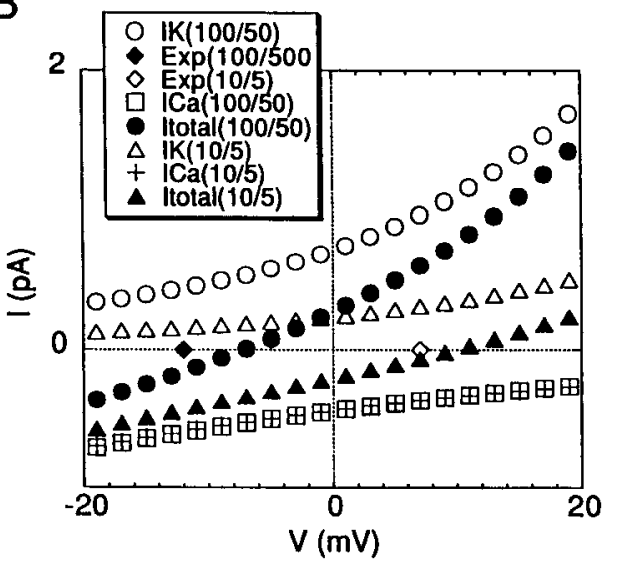

Fig. 5. $\quad I-V$ relations of potassium current $(\bigcirc, \triangle)$, calcium current $(\square,+)$, and total current $(\boldsymbol{O}, \Delta)$ in bi-ionic conditions $\left(100 \mathrm{mM} \mathrm{K} / 50 \mathrm{mM} \mathrm{Ca}{ }^{2+}(\bigcirc, \square, 0)\right.$ and $10 \mathrm{~mm}$ $\left.\mathrm{K}^{+} / 5 \mathrm{mM} \mathrm{Ca}^{2+}(\triangle,+, \boldsymbol{\Delta})\right)$. (A) Single-site channel model. $K_{\mathrm{Ca}}=0.7 \mathrm{mM}$. (B) Two-site model, $h_{1}=h_{2}=0 . K_{\mathrm{Ca}}=0.1 \mathrm{mM}$. $\delta=0.4$. Reversal potentials obtained by experiments in $100 \mathrm{mM} \mathrm{K}^{+} / 50 \mathrm{mM} \mathrm{Ca}^{2+}\left(\right.$ [30]) and in $10 \mathrm{mM} \mathrm{K}^{+} / 5 \mathrm{mM}$ $\mathrm{Ca}^{2+}(\diamond$, unpublished observation).

$5 \mathrm{mM},\left[\mathrm{K}^{+}\right]_{\mathrm{o}}=\left[\mathrm{Ca}^{2+}\right]_{\mathrm{i}}=0$. The ratios of $\mathrm{K}^{+}$and $\mathrm{Ca}^{2+}$ are the same. The calculated reversal potentials in these two conditions are different, and two different values were obtained from the experiments in these two conditions (Fig. 5B).

\section{DISCUSSION}

The values of the reversal potentials in the bi-ionic condition can distinguish this single-file two-site model in which binding sites can bind two monovalent cations or one divalent cation from the model in which each ion permeates through the channel independently (the Goldman-Hodgkin-Katz equation) or from the single-site channel model. If the concentrations of $\mathrm{K}^{+}$and $\mathrm{Ca}^{2+}$ were changed in the bi-ionic condition, keeping the ratio constant, the reversal potentials obtained by the Goldman-Hodgkin-Katz equation or the single-site channel model should be kept constant, but different reversal potentials are obtained. The experimental data support this single-file two-site model in which binding sites can bind two monovalent cations or one divalent cation. Other channels that can permeate both monovalent and divalent cations may be explained by this model, and if they can, ionic currents and reversal potentials of the channel can be calculated from this model. This single-file two-site model may be the best tool with which to understand the ion permeation mechanism of a channel that can permeate both monovalent and divalent cations.

The rate theory is convenient when the pore has definite ion-binding sites with deep potential minima, and ions can pass through the pore only by taking bound states. In this treatment, the probabilities of various types of site occupancies were separately defined and calculated. The interaction between bound ions was taken into consideration through these probabilities; furthermores, the possibility of kicking-out was checked. The comparison with experimental data showed that the probability of kicking-out is negligible. Thus the rate theory is useful to get images of ion permeation in which localized ion binding occurs.

Doyle et al. [27] showed the crystal structure of the potassium channel in which the selectivity filter of the channel contained two potassium ions. Their result supports the idea that the ion channel has ion binding sites in the pore. And the existence of two potassium ion binding sites is consistent with this single-file twosite model. The structure analysis of the channel and the model creation are both important to understand the ion permeation mechanisms of ion channels.

I wish to thank Professor Fumio Oosawa (Aichi Institute of Technology, Japan) for helpful discussions and useful comments on the manuscript.

\section{REFERENCES}

1. Kostyuk PG, Mironov SL, and Shuba YM: Two ion-selecting filters in the calcium channel of the somatic membrane of mollusc neurons. J Membr Biol 76: 83-93, 1983

2. Almers W and McCleskey EW: Non-selective conductance in calcium channels of frog muscle: calcium selectivity in a single-file pore. J Physiol (Lond) 353: 585-608, 1984

3. Almers W, McCleskey EW, and Palade PT: A non-selective cation conductance in frog muscle membrane blocked by micromolar external calcium ions. J Physiol (Lond) 353: 565-583, 1984

4. Hess $P$ and Tsien RW: Mechanism of ion permeation through calcium channels. Nature 309: 453-456, 1984

5. Hess P, Lansman JB, and Tsien RW: Calcium channel selectivity for divalent and monovalent cations: voltage and concentration dependence of single channel cur- 


\section{Y. OOSAWA}

rent in ventricular heart cells. J Gen Physiol 88: 293-319, 1986

6. Coronado R and Affolter $\mathrm{H}$ : Insulation of the conduction pathway of muscle transverse tubule calcium channels from the surface charge of bilayer phospholipid. J Gen Physiol 87: 933-953, 1986

7. Kuo $\mathrm{C}-\mathrm{C}$ and Hess $\mathrm{P}$ : Ion permeation through the Ltype $\mathrm{Ca}^{2+}$ channel in rat phaeochromocytoma cells: two sets of ion binding sites in the pore. J Physiol (Lond) 466: 629-655, 1993

8. Kuo $\mathrm{C}-\mathrm{C}$ and Hess $\mathrm{P}$ : Characterization of the high-affinity $\mathrm{Ca}^{2+}$ binding sites in the L-type $\mathrm{Ca}^{2+}$ channel pore in rat phaeochromocytoma cells. J Physiol (Lond) 466: 657-682, 1993

9. Adams DJ, Dwyer T, and Hille B: The permeability of endplate channels to monovalent and divalent metal cations. J Gen Physiol 75: 493-510, 1980

10. Dani JA and Eisenman G: Monovalent and divalent cation permeation in acetylcholine receptor channels: ion transport related to structure. J Gen Physiol 89: 959-983, 1987

11. Iino M, Ciani S, Tsuzuki K, Ozawa S, and Kidokoro Y: Permeation properties of $\mathrm{Na}^{+}$and $\mathrm{Ca}^{2+}$ ions through the mouse $\varepsilon_{2} / \zeta_{1}$ NMDA receptor channel expressed in Xenopus oocytes. J Membr Biol 155: 143-156, 1997

12. Stern JH, Knutsson $H$, and MacLeish PR: Divalent cations directly affect the conductance of excised patches of rod photoreceptor membrane. Science 236: 1674-1678, 1987

13. Menini A, Rispoli G, and Torre V: The ionic selectivity of the light-sensitive current in isolated rods of the tiger salamander. J Physiol (Lond) 402: 279-300, 1988

14. Colamartino G, Menini A, and Torre V: Blockage and permeation of divalent cations through the cyclic GMP-activated channel from tiger salamander retinal rods. J Physiol (Lond) 440: 189-206, 1991

15. Zimmerman $\mathrm{AL}$ and Baylor DA: Cation interactions within the cyclic GMP-activated channel of retinal rods from the tiger salamander. I Physiol (Lond) 449: 759-783, 1992

16. Picones A and Korenbrot Jl: Permeation and interaction of monovalent cations with the cGMP-gated channel of cone photoreceptors. J Gen Physiol 100: 647-673, 1992

17. Picones A and Korenbrot JI: Permeability and interaction of $\mathrm{Ca}^{2+}$ with the cGMP-gated ion channels differ in retinal rod and cone photoreceptors. Biophys $J$ 69:
120-127, 1995

18. Sesti F, Eismann E, Kaupp UB, Nizzari M, and Torre V: The multi-ion nature of the cGMP-gated channel from vertebrate rods. J Physiol (Lond) 487: 17-36, 1995

19. Haynes LW: Permeation of internal and external monovalent cations through the catfish cone photoreceptor cGMP-gated channel. J Gen Physiol 106: 485-505, 1995

20. Haynes LW: Permeation and block by internal and external divalent cations of the catfish cone photoreceptor cGMP-gated channel. J Gen Physiol 106: 507-523, 1995

21. Wells GB and Tanaka JC: Ion selectivity predictions from a two-site permeation model for the cyclic nucleotide-gated channel of retinal rod cells. Biophys $J$ 72: 127-140, 1997

22. Heinemann SH, Terlau H, Stühmer W, Imoto K, and Numa S: Calcium channel characteristics conferred on the sodium channel by single mutations. Nature 356 : 441-443, 1992

23. Yang J, Ellinor PT, Sather WA, Zhang J-F, and Tsien RW: Molecular determinants of $\mathrm{Ca}^{2+}$ selectivity and ion permeation in L-type $\mathrm{Ca}^{2+}$ channels. Nature 366: 158-161, 1993

24. Favre I, Moczydlowski E, and Schild L: On the structural basis for ionic selectivity among $\mathrm{Na}^{+}, \mathrm{K}^{+}$, and $\mathrm{Ca}^{2+}$ in the voltage-gated sodium channel. Biophys $\mathrm{J}$ 71: 3110-3125, 1996

25. Oosawa $Y$ and Kasai $M$ : Gibbs-Donnan ratio and channel conductance of Tetrahymena cilia in mixed solution of $\mathrm{K}^{+}$and $\mathrm{Ca}^{2+}$. Biophys J 54: 407-410, 1988

26. Oosawa Y: Ionic currents of channels that are permeable to monovalent and divalent cations. Biophys J 56: 1217-1223, 1989

27. Doyle DA, Cabral JM, Pfuetzer RA, Kuo A, Gulbis JM, Cohen SL, Chait BT, and MacKinnon R: The structure of the potassium channel: molecular basis of $\mathrm{K}^{+}$conduction and selectivity. Science 280: 69-77, 1998

28. Oosawa $Y$ and Sokabe $M$ : Cation channels from Tetrahymena cilia incorporated into planar lipid bilayers. Am J Physiol 249: C177-C179, 1985

29. Oosawa $Y$ and Sokabe M: Voltage-dependent aminoglycoside blockade of the sarcoplasmic reticulum $\mathrm{K}^{+}$ channel. Am J Physiol 250: C361-C364, 1986

30. Oosawa Y, Sokabe M, and Kasai M: A cation channel for $\mathrm{K}^{+}$and $\mathrm{Ca}^{2+}$ from Tetrahymena cilia in planar lipid bilayers. Cell Struct Func 13: 51-60, 1988 